Глава 2. Интродукция и сортоизучение

20. Тыщенко Е.Л., Тимкина Ю.В. Методические аспекты оценки декоративных признаков гибискуса сирийского (Hibiscus syriacus L.) // Научный электронный журнал КубГАУ. - 2011. - № 66(02). - [Электронный ресурс] - Режим доступа: http://ej.kubagro.ru/2011/02/pdf/28.pdf

\title{
STUDY OF IRIS SIBIRICA CULTIVARS'S ORNAMENTALITY UNDER THE CONDITIONS OF HUMID SUBTROPICS OF RUSSIA
}

\author{
Slepchenko N. A., Slepchenko K. V. \\ Federal Research Centre \\ the Subtropical Scientific Centre of the Russian Academy of Sciences, \\ Sochi, Russia,e-mail: slepchenko@vniisubtrop.ru
}

The introduction work includes the study of cultivars and the selection of promising assortments. In recent years, there has been an increasing interest in beardless irises, which include Iris sibirica. The studies were carried out on the experimental base of FRC SSC RAS in 2018-2020, on Iris sibirica collection, applying the developed methodology. As a result of the observations, the criteria for assessing ornamental qualities, which are the most important in landscaping, were refined, and the assessment cards were tested. The ornamentality of the studied $I$. sibirica cultivars and hybrids was evaluated. The following cultivars with high ornamental scores were identified: 'Double Standards' - 58.18, 'Kita-No-Seiza' 58.09, 'Biyskiye perecaty' - 56.64, 'Lemon Veil' - 56.91, 'King of Kings' - 55.88.

Key words: Iris sibirica, introduction, collection, cultivars, assortment, method of study, evaluation of ornamentality, cultivar study, humid subtropics.

УДК 635.9

doi: 10.31360/2225-3068-2020-75-33-38

\section{ОСЕННЕЦВЕТУЩИЕ АМАРИЛЛИСОВЫЕ В УСЛОВИЯХ ВЛАЖНЫХ СУБТРОПИКОВ РОССИИ}

\author{
Слепченко К. В., Загудаева Ю. С. \\ Федеральное государственное бюджетное учреждение науки \\ «Федеральный исследовательский иеентр «Субтропический научный иентр \\ Российской академии наук», \\ 2. Сочи, Россия, e-mail: slepchenko@vniisubtrop.ru
}

Расширение ассортимента цветочных растений позволит использовать их в различных формах цветочного оформления, на выгонку и срез, даст толчок дальнейшему развитию отечественного цветоводства. Сохранение, поддержание и изучение коллекции луковичных цветочных культур защищённого грунта отдела цветоводства из семейства Amaryllidaceae, выделение видов с осенним и позднеосенним цветением - цель работы. В результате проведённых исследований осеннецветущие представители семейства сгруппировали по срокам цветения, окраске долей околоцветника и высоте цветоноса. Большая часть видов цвела в октябре, имела окраску различной интенсивности розового цвета и высоту цветоноса $30-50 \mathrm{~cm}$. 
Ключевые слова: Амариллисовые, интродукция, коллекция, вид, сроки цветения, оценка декоративности, сортоизучение, влажные субтропики.

Мобилизация, сохранение и изучение генетического разнообразия культурных растений позволяет всесторонне использовать их в фундаментальных и прикладных исследованиях. Цветочные культуры являются частью биологических ресурсов, имеют большую ценность и значимость при решении вопросов экологической безопасности. Помимо глобальных целей сохранения биоразнообразия, они несут и эстетические. Расширение ассортимента цветочных растений позволит использовать их в различных формах цветочного оформления, на выгонку и срез, даст толчок дальнейшему развитию отечественного цветоводства.

Коллекции цветочных культур, в том числе из семейства Амариллисовые (Amaryllidaceae) имеются во многих научных учреждениях (ботанических садах, научно-исследовательских институтах и центрах) [1, 3-7, 15-17].

В коллекции ФИЦ СНЦ РАН поддерживается коллекция цветочнодекоративных культур из разных флористических районов земного шара, включающая луковичные культуры, которые возделываются в условиях открытого и защищённого грунта $[8,9,11]$. Многочисленные представители семейства Amaryllidaceae могут быть использованы в зоне влажных субтропиков, в том числе в рамках импортозамещения $[13,10]$.

Цель исследований - сохранение, поддержание и изучение коллекции луковичных цветочных культур защищённого грунта отдела цветоводства из семейства Amaryllidaceae, выделение видов с осенним и позднеосенним цветением.

Объекты и методы исследований. Исследования проводили на опытной базе ФИЦ СНЦ РАН в с. Раздольное Хостинского р-на гор. Сочи в 2018-2020 гг. на коллекции семейства Amaryllidaceae. Сортообразцы изучали по методикам, разработанным сотрудниками Центра [2].

Объекты исследований - виды 3 родов (Nerine Herb., Amaryllis L., Lycoris Herb.)., разнообразные по форме, высоте и окраске. Родиной Nerine и Amaryllis является Южная Африка, Lycoris - Дальний Восток [14]. Опыт заложили в парниках, которые на зимний период закрывали пленкой. В течение всего сезона проводили все необходимые агротехнические мероприятия.

Район исследований относится к зоне влажных субтропиков. Средняя годовая температура воздуха составляет $+14,1{ }^{\circ} \mathrm{C}$. Температура января и февраля $-+6,0 \ldots 6,1^{\circ} \mathrm{C}$, июля и августа $-+23,2 \ldots 23,6^{\circ} \mathrm{C}$. Средний абсолютный минимум температуры достигает $-7^{\circ} \mathrm{C}$. Регион характеризуется выпадением большого количества осадков, средняя годовая норма составляет 1635 мм, преимущественно ливневого характера. 
Осадки в виде снега в прибрежной зоне явление редкое, снежный покров неустойчивый [12].

Результаты исследований. В результате проведённых фенологических наблюдений, установлены виды, цветущие в условиях влажных субтропиков России (г. Сочи) в поздние сроки. В летне-осенний период цвели Amaryllis belladonna Wat и Brunsdonna (Amaryllis belladonna $\times$ Brunsvigia) и Nerine huttoniae Schönland (табл. 1). Затем, в раннеосенний - Lycoris radiata (L. Herit.) Herb. В середине осени отмечали цветение Nerine sarniensis (L.) Herb. и N. undulata (L.) Herb. Наиболее позднее и продолжительное цветение наблюдали у Nerine bowdenii W. Watson.

Таблийа 1

Сроки цветения осеннецветущих представителей семейства Amaryllidaceae на Черноморском побережье России

\begin{tabular}{|c|c|c|c|c|c|}
\hline \multirow{2}{*}{ Культура } & \multicolumn{5}{|c|}{ Период цветения } \\
\hline & VIII & IX & $\mathrm{X}$ & XI & XII \\
\hline Amaryllis belladonn & & & & & \\
\hline Brunsdonna & & & & & \\
\hline Lycoris radiata & & & & & \\
\hline Nerine huttoniae & & & & & \\
\hline Nerine_sarniensis & & & & & \\
\hline Nerine undulata & & & & & \\
\hline Nerine bowdenii & & & & & \\
\hline
\end{tabular}

Окраска долей околоцветника (табл. 2) разнообразная, может быть белой, разных оттенков красного, розового, малинового цвета. Большее число видов имели окраску различной интенсивности розового цвета.

Высота цветоносов также различна: низкая (до 30 см) у Nerine huttoniae, средняя (30-50 см) у Lycoris radiate, Nerine sarniensis, N. undulate, $N$. bowdenii и высокая (свыше 50 см) у Amaryllis belladonna и Brunsdonna.

В условиях влажных субтропиков России Amaryllis belladonna Lycoris radiate, Brunsdonna и Nerine huttoniae цвели без листьев. Nerine sarniensis, $N$. undulate, $N$. bowdenii с листьями. 


\section{Высота растений и окраска долей околоцветника у изучаемых видов}

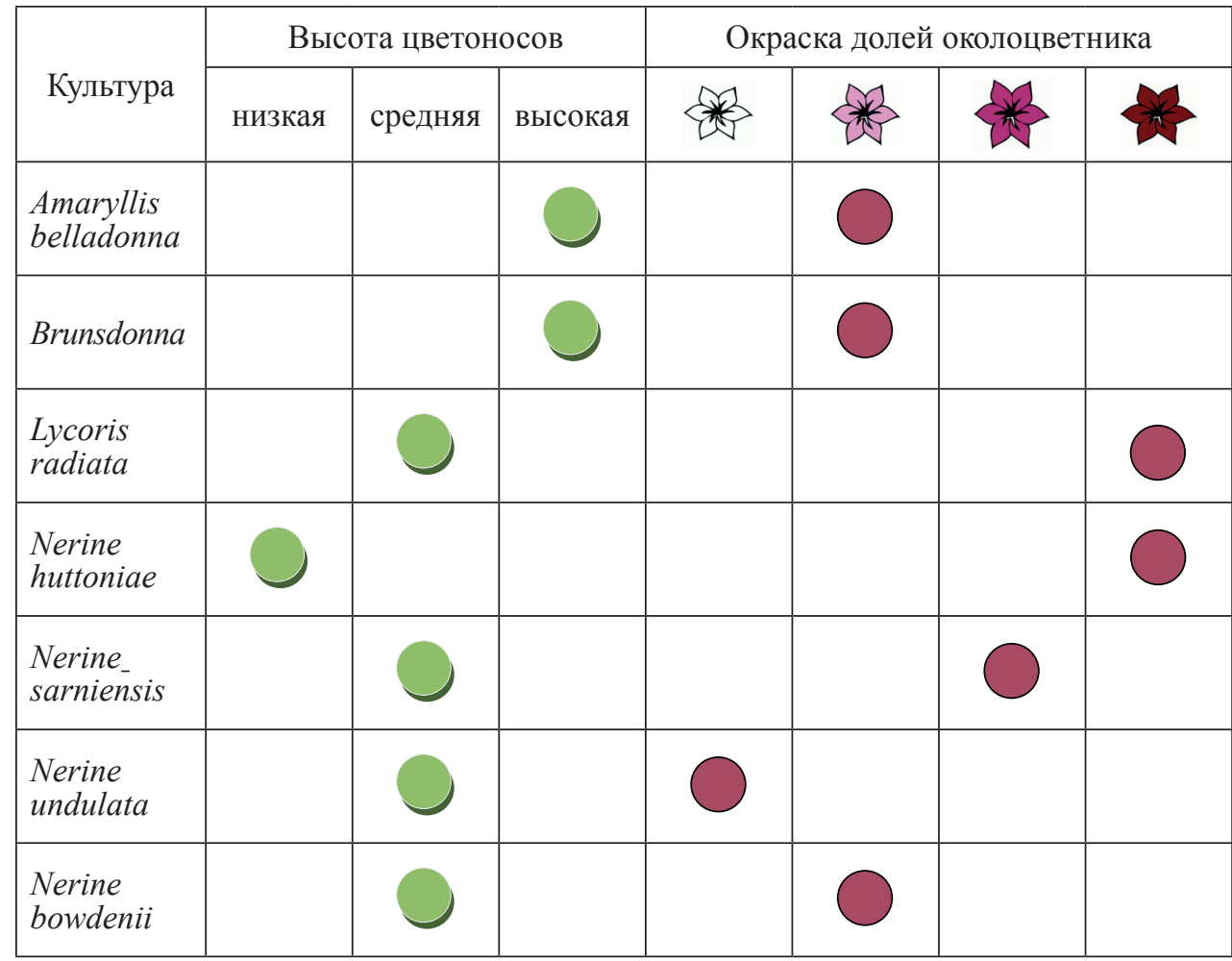

Заключение. Таким образом, в результате проведённых исследований осеннецветущие представители семейства сгруппировали по срокам цветения, окраске долей околоцветника и высоте цветоноса. Большая часть видов цвела в октябре, имела окраску различной интенсивности розового цвета и высоту цветоноса 30-50 см.

\section{Библиографический список}

1. Архипова И.Н., Сорокопудова О.А., Сушкова О.В. Сроки цветения видов и сортов некоторых родов семейства Amaryllidaceae Jaume St.-H. в оранжерее зимнего сада // Научные ведомости Белгородского государственного университета. Серия: Естественные науки. - 2011. - Т. 15. - № 9-1(104). - С. 136-139.

2. Болгов В.И., Евсюкова Т.В., Козина В.В., Пустынников М.А. Методика первичного сортоизучения цветочных культур. - М.: РАСХН, 1998. - 40 с.

3. Воробьёва А.С., Сорокопудова О.А. Перспективы создания коллекции представителей семейства Amaryllidaceae в Белгороде // Научные ведомости Белгородского государственного университета. Серия: Естественные науки. - 2012. - Т. 21. - № 21-1(140). - С. 82-86. 4. Ефимов С.В., Дворцова В.В., Дацюк Е.И., Смирнова Е.И. Этапы формирования коллекций декоративных растений в ботаническом саду МГУ им. М. В. Ломоносова // Субтропическое и декоративное садоводство. - 2014. - Вып. 50. - С. 70-84. - ISSN 2225-3068. 
Глава 2. Интродукция и сортоизучение

5. Завадская Л.В. Редкие нарциссы коллекции Центрального ботанического сада НАН Беларуси // Цветоводство: история, теория, практика: мат. VII междунар. науч. конф., г. Минск, Беларусь, 24-26 мая 2016 г. - Минск: Конфидо, 2016. - С. 120-121. - ISBN 978-985-6777-82-3.

6. Карпун Ю.Н., Кувайцев М.В., Бобровская А.К. Субтропический ботанический сад Кубани: каталог. - Сочи, 2012. - 58 с.

7. Коротких А.С. Интродукция нарциссов в Белгородском ботаническом саду // Субтропическое и декоративное садоводство: сб. науч. тр. - Сочи: ВНИИЦиСК. - 2015. - Вып. 54. - С. 46-50. - ISSN 2225-3068.

8. Лобова Т.Е., Слепченко Н.А. К вопросу о возделывании нерины Боудена и амариллиса белладонна на Черноморском побережье России // Субтропическое и декоративное садоводство: сб. науч. тр. - Сочи: ВНИИЦиСК, 2010. - Вып. 43. - Т. II. - С. 59-63. 9. Лобова Т.Е., Слепченко Н.А. Руководство по возделыванию нерины Боудена // Субтропическое и декоративное садоводство: сб. науч. тр. - Сочи: ВНИИЦиСК, 2016. Вып. 56. - С. 157-169. - ISSN 2225-3068.

10. Рындин А.В., Келина А.В., Слепченко Н.А., Клемешова К.В. Перспективы импортозамещения в декоративном садоводстве субтропической зоны России // Субтропическое и декоративное садоводство. - 2015. - Вып. 55. - С. 19-26. - ISSN: 2225-3068. 11. Рындин А.В., Слепченко Н.А. Цветочно-декоративные культуры в ФГБНУ ВНИИЦиСК: состояние и пополнение коллекций // Научные труды Северо-Кавказского федерального научного центра садоводства, виноградарства, виноделия. - 2019. - T. 25. - C. 206-210. - doi: 10.30679/2587-9847-2019-25-206-210.

12. Рындин А.В. Агроэкологические аспекты садоводства влажных субтропиков России. - Сочи: ВНИИЦиСК, 2016. - 260 с. - ISBN: 978-5-904533-29-8.

13. Слепченко Н.А., Карпун Н.Н. Использование редких и исчезающих видов природной флоры Кавказа в садово-парковых ландшафтах района Сочи, как способ их охраны // Вестник ИрГСХА. - 2011. - Вып. 44. - Ч. VII. - С. 130-133. - ISSN 1999-3765.

14. Слепченко Н.А., Лобова Т.Е. Нерина - яркое украшение южной осени // Цветоводство. - 2014. - № 5. - С. 28-29. - ISSN 0041-4905.

15. Слепченко Н.А., Лобова Т.Е. Представители семейства Amaryllidaceae Jaume Saint-Hilaire в декоративном садоводстве в субтропической зоне Черноморского побережья России // Субтропическое и декоративное садоводство. - 2013. - Вып. 48. - C. 62-72. - ISSN 2225-3068.

16. Слепченко Н.А., Лобова Т.Е. Способность к размножению нерины Боудена (Nerine bowdenii) в условиях влажных субтропиков России // Известия Тимирязевской сельскохозяйственной академии. - 2018. - Вып. 5. - С. 103-110. - doi: 10.26897/0021342Х-2018-5-103-110.

17. Сорокопудова О.А. Итоги интродукции некоторых декоративных травянистых многолетников в Белгороде // Актуальные вопросы плодоводства и декоративного садоводства в начале XXI века: мат-лы научно-практ. конф., 22-26 сентября 2014, г. Сочи. - Сочи: ВНИИЦиСК, 2014. - С. 194-202.- ISBN 978-5-904533-21-2.

\section{AUTUMN-FLOWERING AMARYLLIS FAMILY UNDER THE CONDITIONS OF HUMID SUBTROPICS OF RUSSIA}

Slepchenko K. V., Zagudayeva Yu. S. 
Субтропическое и декоративное садоводство (75)

Federal Research Centre

the Subtropical Scientific Centre of the Russian Academy of Sciences,

Sochi, Russia,e-mail: slepchenko@vniisubtrop.ru

The expansion of flower plants assortment will allow them to be used in various forms of flower decoration, for forcing and cutting, and will provide the further development of domestic floriculture. Conservation, maintenance and study of bulbous flowers collection from Amarulidaceae family growing in the protected soil of the Floriculture Department, as well as selection of species with autumn and late autumn flowering are the purpose of this work. As a result of the conducted studies, the autumnflowering representatives of the family were grouped according to the flowering time, perianth lobe colour and peduncle height. Most of the species flowered in October, had a pink colour of varying intensity and a peduncle height of $30-50 \mathrm{~cm}$.

Key words: Amaryllidaceae, introduction, collection, cultivars, flowering time, evaluation of ornamentality, cultivar study, humid subtropics.

УДК 631.524.6.(477/470.21)

doi: $10.31360 / 2225-3068-2020-75-38-48$

\title{
РАСТЕНИЯ АЛТАЯ ИЗ СЕМЕЙСТВ RANUNCULACEAE JUSS. И PAEONIACEAE RUDOLPHI В УСЛОВИЯХ КОЛЬСКОГО СЕВЕРА
}

\section{Юдин С. И.}

\author{
Федеральное государственное бюджетное научное учреждение \\ «Полярно-альпийский ботанический сад-институт им. Н. А. Аврорина \\ Кольского научного иентра Российской академии наук», \\ 2. Кировск, Россия, e-mail: yudin.pabgi@yandex.ru
}

Представлены результаты многолетнего изучения ритмов сезонного развития растений 43 видов семейств Ranunculaceae Juss. и Paeoniaceae Rudolphi флоры Горного Алтая в условиях Кольского Севера (г. Кировск, Мурманская область). Выявлены особенности роста и развития этих растений в условиях культуры. Установлено, что при интродукции многие растения Горного Алтая успешно проходят весь цикл роста и развития, плодоносят, наблюдается самосев в новых условиях. Сравнительное изучение условий произрастания, сезонного ритма, онтогенеза растений двух наиболее контрастных для горных районов экотипов (предгорного и высокогорного) одного и того же вида в одинаковых условиях первичной культуры позволяет выявить, что условиям северной тайги Хибинских гор Кольского полуострова в большей степени соответствуют растения высокогорных местообитаний (высокогорный экотип). Особенности роста и развития растений алтайских видов ex situ свидетельствуют об успешной адаптации большинства этих видов к условиям Кольского Заполярья.

Ключевые слова: Ranunculaceae и Paeoniaceae, интродукция, экотип, Горный Алтай, Кольский Север. 